DOI

\title{
СКЛАДОВІ ЯКІСНОЇ ІНТЕРНАТУРИ 3 ФАХУ “ВНУТРІШНІ ХВОРОБИ”
}

\author{
О. І. Криськів, Т. Б. Лазарчук, Л. С. Бабінець, В. М. Творко \\ ДВНЗ “Тернопільський державний медичний університет \\ імені І. Я. Горбачевського МОЗ України”
}

\section{COMPONENTS OF QUALITY INTERNSHIP ON SPECIALTY “INTERNAL DISEASES”}

\author{
O. I. Kryskiv, T. B. Lazarchuk, L. S. Babinets, V. M. Tvorko \\ SHEI "Ternopil State Medical University by I. Ya. Horbachevsky of MPH of Ukraine"
}

\begin{abstract}
У статті проаналізовано проблемні питання викладання внутрішніх хвороб в інтернатурі та можливі шляхи їх вирішення.
\end{abstract}

The article analyzes the problematic issues of teaching of internal diseases in internship and possible ways of their solutions.

Вступ. Проблема удосконалення післядипломного навчання у сучасних умовах надзвичайно актуальна. Адже мова йде про майбутнє держави і нації, забезпечення стратегічного курсу України до Європейського Союзу. Інтеграція освіти, у т. ч. післядипломної, в Європейський освітній простір вимагає координації з директивами Євросоюзу та Всесвітньої федерації медичної освіти (ВФМО). Серед них забезпечення стандартів якості освіти згідно з вимогами ВФМО та конкурентоспроможності професійної підготовки [1].

У час надшвидкого науково-технічного прогресу проблема підготовки висококваліфікованих фахівців набуває все більшого значення. Сучасне суспільство ставить перед випускниками медичного ВНЗ особливі вимоги: професіоналізм, активність, навички спілкування на основі взаєморозуміння, здатність швидко приймати рішення.

Щоби наше суспільство отримувало таких лікарів, система медичної освіти повинна бути орієнтована на нові методи навчання, формування позитивної мотивації якісної i, по можливості, творчої діяльності лікарів-інтернів. Це можливо через впровадження методів навчання за Європейською кредитно-трансферною системою. Зараз майбутні наші інтерни ще навчаються за кредитно-модульною формою Болонської системи. Обидві форми навчання характеризуються високим рівнем інтелектуального й емоційного напруження, спрямованого на засвоєння широкого спектра знань і вмінь.

(ㄱ О. І. Криськів, Т. Б. Лазарчук, Л. С. Бабінець, В. М. Творко
Основна частина. На етапі інтернатури перед викладачами стоїть завдання закріпити і розвинути знання, отримані на додипломному рівні, прищепити потребу безперервного самовдосконалення. Постійною залишається проблема: випускник медичного ВНЗ не достатньо чітко уявляє лікарську діяльність, досить часто не має інтересу до її змісту і завдань. Якісне навчання залежить від обраної ВНЗ системи навчання, педагогічної майстерності викладача і його знань, рівня знань самого інтерна i його мотивації щодо оволодіння цими знаннями.

Викладач-фахівець у роботі з інтернами враховує: 1) який рівень знань потрібно передати; 2) рівень підготовки інтерна; 3) рівень інтелекту. Адже здатність людини засвоювати інформацію - величина індивідуальна і постійна для кожної людини і характеризує пропускну здатність каналів інформації. Як відомо, існує 5 рівнів знань: уявлення, знання, вміння, професійність, творчість [2].

Щоби якісно вчити, викладач повинен вибрати спосіб подачі інформації, який сприяє збільшенню об’єму засвоєння її. При великому об’ємі інформації засвоєння в інтерна відбувається на першому рівні знань, а саме: уявлення. Отже, якщо зменшити об’єм інформації, то цей рівень підвищується. Це перший шлях до збільшення об’єму засвоєння інформації. Зменшити об'єм означає відібрати тільки необхідну інформацію. Тоді засвоєння нового (чи відносно нового) матеріалу відбувається на третьому-четвертому рівнях знань - уміння або професійність. 3 огляду на це, пропедевтичні 
знання лікаря-інтерна з обстеження хворого, враховуючи 5 років навчання з терапії у медичному ВН3, повинні бути на рівні уміння. В інтернатурі досягнути професійності складно, бо лікаріінтерни не працюють самостійно, а весь час під наглядом старших колег. Всі ми знаємо, що саме самостійність спонукає до удосконалення і пошуку, а відповідальність породжує професійну активність і зацікавленість.

Другий шлях до збільшення об’єму засвоєння інформації - це задіяння більшої кількості каналів інформації через використання наочності. Тоді у слухачів активно працює зір, слух, емоційна сфера. Так і ми використовуємо мультимедійну презентацію, навчальні фільми, відеоролики.

Об’єм інформації можна змінювати. Чим менший об’єм інформації, тим вищий рівень засвоєння. Кожен викладач повинен пам’ятати, що при великому об’ємі засвоєння знань відбувається на рівні уявлення. Якщо підібрати лише найнеобхідніший матеріал для лекції, то засвоєння її пройде на третьому-четвертому рівнях знань. Такими мають бути клінічні лекції: повинні розглядатись тільки найважливіші проблеми, що приведуть до вирішення типових і нетипових проблемних завдань. Решта матеріалу підлягає опануванню на семінарських і практичних заняттях та самостійному вивченню.

До навчальних занять у ВНЗ належать: лекція, семінар, лабораторне заняття, практичне заняття, індивідуальне заняття, навчальна конференція, консультація, навчальна гра та ін. Провідною формою організації процесу навчання у ВНЗ є лекція. Існують такі види лекцій: вступна, інформаційна, заключна, оглядова.

У роботі з інтернами ми практикуємо дві форми лекцій: класичні і проблемні. Класична лекція традиційна форма навчання, що знайомить інтернів із блоком логічно завершеної наукової інформації з певної теми і включає послідовне, грунтовне викладення матеріалу, починаючи з актуальності теми, етіопатогенезу і завершуючи сучасним лікуванням.

Теоретично клінічну лекцію краще читати не як класичну, тому що через обмежений лекційний час складно у повному об’ ємі послідовно викласти матеріал, а як проблемну. Інтерни теж більш схильні почути проблемну лекцію. Проте до проблемної лекції інтерн повинен підготуватись по ключових питаннях. Це необхідно для того, щоби під час лекції інтерни були активними слухачами і вступали у дискусію, аргументовано відстоювали свою точку зору. Реально на подібних лекціях дискусія млява, інколи відсутня, і переважає форма участі інтерна “запитання - відповідь”. А ось лікарі-курсанти, для порівняння, зазвичай добре готові до проблемної лекції, і дискусія ведеться жваво, із розумінням суті проблеми чи клінічної ситуації, що обговорюється. Очевидно, у даному випадку вагоме значення мають досвід практичної роботи і високий рівень знань курсанта, тобто професійність і творчість. Лікарі ж інтерни оперують знаннями на рівнях знання і вміння. Зазначимо, що за кордоном більш поширеною є лекція-дискусія. Супровід проблемної чи класичної лекцій на нашій кафедрі відповідає вимогам сьогодення: мультимедійна презентація, відеоролики, демонстрація на екрані ЕКГ, ехо-КГ, Ro-знімків, результатів загальноклінічних та спеціальних методів обстеження, клінічний розбір хворого.

Вартий уваги той факт, що якщо лекція прочитана окремо від теми семінарських і практичних занять, то рівень засвоєння матеріалу дуже низький - лише 3 \% [3]. Таким чином, маємо деяку невідповідність у навчальному процесі в інтернатурі: на лекції відводиться лише 5 \% від навчальних годин. Наприклад: на першому році навчання інтерни фаху “Внутрішні хвороби” мають 34 години лекцій, а навчальних годин із предмета в році - 562. Лекційні теми досить обширні. Отже, прочитати лекцію, дотримуючись логічної послідовності “лекція - семінар - практичне заняття”, неможливо. Поглиблює цю розбіжність і те, що розклад дисципліни “Внутрішні хвороби” нерідко переривається суміжними дисциплінами, а лекційний день проводять здебільшого для всіх груп інтернів, тобто з різною тематикою навчання. Читання же лекцій для 1 чи 2 груп відповідно до розділу, що вивчається, автоматично збільшує кількість лекційних годин і потребує більшої кількості викладачів.

Упродовж декількох років на кафедрі проводять ранкові лікарські конференції, які самі ж інтерни модернізували мультимедійною презентацією [4]. За час інтернатури кожен лікар-інтерн виступає 4-6 разів на такій конференції. Це пробудило живий інтерес у молодих лікарів до аналізу побудови лекцій і мультимедійних презентацій викладачів. Дещо вони почали запозичувати. Тепер їхні презентації оформлені більш естетично, доповнені малюнками, EKГ, Ro-знімками. Інтерн, який добре підготувався до конференції і має міцний фундамент знань, впевнено і доповідає, і відповідає на запитання, 
незважаючи на хвилювання. Під час ранкових конференцій періодично простежується одна із колізій навчального процесу, а саме: знання інтерна поки ще $є$ на рівні вміння (а по деяких питаннях і на рівні уявлення), а викладачі розглядають проблему на рівнях професійності і творчості. Допомагає вирішувати ситуацію толерантність і надія на постійне, безперервне навчання лікаря-інтерна.

Якісні знання базуються на закріпленні теоретичних знань і досконалому володінні практичними навичками. Під час навчання в інтернатурі на практичних заняттях ми проводимо тестовий контроль (із визначенням базового, проміжного чи заключного рівня знань), поєднуючи його із клінічним розбором хворого та довільними методами аналізу ситуацій. Всі без винятку інтерни надають перевагу двом останнім формам роботи, тому що мають змогу взяти безпосередню участь в обговоренні ситуації i, навіть, подискутувати з викладачем. Так, у процесі спілкування і співпраці збільшується довіра між викладачем та лікарем-інтерном, є можливість визначити реальне завдання для подальшої самостійної роботи кожного майбутнього лікаря.

Міжпредметна інтеграція - необхідна складова

\section{Список літератури}

1. Ковальчук Л. Я. Реорганізація післядипломної освіти - важливий аспект наступного розвитку охорони здоров’я в Україні / Л. Я. Ковальчук // Медична освіта. - 2014. - № 2. - С. 27-33.

2. Фіцула М. М. Педагогіка вищої школи: навч. посіб. / М. М. Фіцула. - К. : Академвидав, 2006. - 352 с.

3. Швець Н. І. Оптимізація навчального процесу у закладах післядипломної освіти / Н. І. Швець // Світ медицини та біол. - 2011. - № 3. - С. 162-164. усіх форм роботи з інтернами. Вона сприяє формуванню логічного мислення і дозволяє створювати цілісну картину конкретного клінічного випадку. Так, інтерни починають розуміти, що міцні базові знання усувають невпевненість початківця і закладають міцне підгрунтя для лікарської роботи 3 мінімальною кількістю помилок.

Самостійна позааудиторна робота необхідна і для реалізації навчального плану, і для формування та закріплення навичок лікаря до безперервної освіти. Завдання для позааудиторної роботи отримують всі інтерни в групі відповідно до теми заняття. Цікавим $€$ те, що навіть побіжний контроль цих знань на наступних заняттях не тільки їх дисциплінує і оцінює, а й створює позитивну мотивацію в успішному набутті наступних знань. Це також збільшує самооцінку кожного інтерна зокрема і рейтинг їх у групі.

Висновок. Комплексний підхід до вирішення актуальних питань навчання в інтернатурі дозволить підвищити професійний рівень майбутніх лікарів-терапевтів.

4. Криськів О. І. Деякі аспекти підвищення ефективності практичної підготовки лікарів-інтернів фаху “Загальна практика - сімейна медицина” / О. І. Криськів, Т. Б. Лазарчук, Л. В. Зоря // Досягнення і перспективи впровадження кредитно-модульної системи організації навчального процесу у вищих медичних (фармацевтичному) навчальних закладах України : тези доп. навч.наук. конф. - Тернопіль, 2014. - Ч. 2. - С. 461-462.

Отримано 16.06.15 